\title{
U
}

International Journal of Recent Development in Engineering and Technology

Website: www.ijrdet.com (ISSN 2347 - 6435 (Online) Volume 10, Issue 1, June 2021)

Manuscript Received: 10 Feb 2021, Received in Revised Form: 15 May 2021, Accepted: 18 June 2021 DOI: 10.54380/IJRDETV10I105

\section{Impact of Silica on Geotechnical Properties of Clayey Soil Present in Edfu- Aswan, Egypt.}

\author{
Ashraf Ghanem ${ }^{1}$, El-Sharif, M. Abdel- Aziz ${ }^{2}$ \\ ${ }^{l}$ M.Sc. Civil Eng Dept., Faculty of Eng., Assiut University \\ ${ }^{2}$ professor of Soil Mechanics and Foundations, Civil Eng. Dept., Assiut University
}

${ }^{1}$ eng top@hotmail.com

\begin{abstract}
It may be necessary to improve the engineering properties of clayey soils to make them suitable for construction by using some kind of stabilization methods. Treatment with lime, cement or waste materials such as silica fume (SF) has traditionally been used for the stabilization of clayey soils. The soil chosen in this research was extracted from a site in Edfu- Aswan, Egypt. Investigating the effect of properties of cohesive soils when mixed with SF is the main objective of this study. Silica fume is a mineral made up of ultra-fine solid, amorphous silicon dioxide glass spheres (SiO2) from the metallurgical industries company (E.JS.C) in Edfu. A series of laboratory experiments for samples prepared with different percentages were implemented of SF $0 \%, 2 \%, 4 \%, 6 \%, 8 \%$, and $10 \%$. The results show that the blend will increase the maximum dry density of clayey soils. Their Plasticity Index and the liquid limit would increase, the permeability of clayey soil decreases, the unconfined compression strength will increase.
\end{abstract}

All of these results can be summarized to say that the engineering properties of cohesive soils can be improved by combining Silica Fume and clayey soils together.

Keywords - Waste Material, Soil Stabilization, Cohesive Soils, Silica Fume, Lime.

\section{INTRODUCTION}

Finding the subgrade to be clay uncovers a difficult civil engineering problem. The high content of clay in clay soils increases the tendency to swell their moisture content allowance. This moisture may result from rains, floods, sewer lines leaking, or surface evaporation reduction when a building or pavement covers an area. Quite often, these clay soils are responsible for the cracking and breaking of pavements, highway embankments, roads, railways, foundations, and channel or reservoir lines. The improvement of both strength and durability of the soil is implied for soil stabilization in its broadest sense. Adding deficient particle sizes may improve the soil as it gives a more satisfactory grading. Soil is using cement, bitumen, lime or special additives to bind or waterproof the particles of soil and so increase its durability and strength by a process known as mechanical stabilization.

Stabilization also applies waste materials or nontraditional stabilizers like Fly ash and Silica Fume. Stabilized soil is when the soil has been mixed with any of the mixtures mentioned above. Using Silica Fume as a stabilizer is a focus of this study.

Silica Fume is a highly effective pozzolanic material containing silicon dioxide, $\mathrm{SiO}_{2}$, reacts with clay minerals (aluminium oxide, $\mathrm{Al}_{2} \mathrm{O}_{3}$ ) and produces Aluminium silicate hydrate (A-S-H). Aluminium silicate is a type of fibrous material and considered cemented material made of aluminium oxide and silicon dioxide, ) but the effect of add of silica fume has a little effect up to $5 \%$ because there is no reaction between aluminium oxide and silicon dioxide.

Silica fume (SF), also referred to as micro silica, is defined as a by-product of the reduction in silicon and ferrosilicon alloy production of high purity quartz with coal in electric furnaces. It is also collected as a by-product of other silicon alloys such as ferromagnesium, ferrochromium, silicon calcium, and ferromanganese. It becomes economically justified to use Silica fume in various applications; after the collection and landfilling of (SF) was necessitated by environmental concerns. SF consists of very fine vitreous particles with a surface area of approximately $20,000 \mathrm{~m}^{2} / \mathrm{kg}\left(215,280 \mathrm{ft}^{2} / \mathrm{lb}\right)$ when measured using nitrogen absorption techniques, with particles about 100 times smaller than the average cement particle. (SF) It is a pozzolanic material that is extremely efficient because of its high silica content and extreme finesse. To improve properties Concrete uses Silica Fume. It has been found that SF bonds strength and resistance to abrasion, reduces permeability and improves compressive strength and thus helps protect steel from corrosion.

SF comes in two conditions: wet and dry. Dry silica can be supplied with or without dry admixtures as densified or produced and can be stored in hopper and silos. (SF) is available with high or low dosages of chemical admixtures. 


\begin{tabular}{|c|c|c|c|}
\hline \multicolumn{4}{|c|}{$\begin{array}{l}\text { International Journal of Recent Development in Engineering and Technology } \\
\text { Website: www.ijrdet.com (ISSN } 2347 \text { - } 6435 \text { (Online) Volume 10, Issue 1, June 2021) }\end{array}$} \\
\hline Received: 10 Feb 2021, Received in Revised Form: 1 & ted: 18 June 20 & I: 10.543 & TV101105 \\
\hline \multirow{2}{*}{$\begin{array}{l}\text { Received: } 10 \text { Feb 2021, } \text { Received in Revised Form: } 1 \text {. } \\
\text { ts are stored in tanks ranging from a few } \\
\text { s to } 400,000 \text { gallons }(1,510 \mathrm{~m} 3)[5,6] .\end{array}$} & O.M.C & $21 \%$ & $21.17 \%$ \\
\hline & L.L & $52.7 \%$ & $34.5 \%$ \\
\hline \multirow{6}{*}{$\begin{array}{l}\text { II. EXPERIMENTAL WORK } \\
\text { of the use of (SF) was studied on the } \\
\text { echanical properties of silty clay (soil A) } \\
\text { ayey silt soil was studied. The tests were } \\
\text { ixed cohesive soil with a different amount } \\
\%, 4 \%, 6 \%, 8 \% \text {, and } 10 \% \text { ) by weight of the } \\
\text { properties of soils include classification, } \\
\text {, compaction characteristics, shear strength } \\
\text { consolidation behavior. }\end{array}$} & P.L & $25.7 \%$ & $24.6 \%$ \\
\hline & P.I & $27 \%$ & $9.9 \%$ \\
\hline & S.L & $13.1 \%$ & 20.53 \\
\hline & Clay content & $14 \%$ & $20 \%$ \\
\hline & Silt content & $77 \%$ & $51 \%$ \\
\hline & Sand & $9 \%$ & $29 \%$ \\
\hline
\end{tabular}

\section{A. TEST SOILS}

The soils tested in this investigation were extracted from an open pit in Edfu- Aswan, Egypt. There was disturbance to the soil samples. The physical characterization of silty clay and clayey silt is shown in Table 1. Table 3 shows the chemical element of the tested materials. The distribution of the natural grain size of the tested soils is shown in fig (1). soil (A) is classified According to the ASSHTO soil classification system as A-7-6, and soil (B) classified as A6.

\section{B. STABILIZER PRODUCT}

The materials used in this study for the stabilizer were (SF). (SF) products were brought from Ferrosilicon Alloys Company (Edfu), Aswan, Egypt. SF minerals' composition is presented in table 2. The laboratory test was done in Soil Mechanics and Foundations Laboratory, Assiut University.

TABLE I

SHOWS THE CLAYEY SOIL PROPERTIES

\begin{tabular}{|c|c|c|}
\hline $\begin{array}{c}\text { Physical } \\
\text { Properties }\end{array}$ & Soil(A) & Soil(B) \\
\hline$\gamma \mathrm{d} \max$ & $1.62 \mathrm{gm} / \mathrm{cm}^{3}$ & $1.73 \mathrm{gm} / \mathrm{cm}^{3}$ \\
\hline
\end{tabular}

Slurred products are stored in tanks ranging from a few

The impact of the use of (SF) was studied on the physical and mechanical properties of silty clay (soil A) performed by mixed cohesive soil with a different amount of the (SF) $(0,2 \%, 4 \%, 6 \%, 8 \%$, and $10 \%)$ by weight of the dry soil. The properties of soils include classification, parameters, and consolidation behavior. thousand gallons to 400,000 gallons $(1,510 \mathrm{~m} 3)[5,6]$.

TABLE I 


\begin{tabular}{|c|c|c|c|}
\hline \multicolumn{4}{|c|}{ Manuscript Received: 10 Feb 2021, Received in Revised Form: 15} \\
\hline No & $\begin{array}{l}\text { Molecular } \\
\text { Formula }\end{array}$ & Soil (A) & Soil (B) \\
\hline 1 & $\mathrm{Si}_{2}$ & $34.21 \%$ & $33.04 \%$ \\
\hline 3 & $\mathrm{SO}_{3}$ & $4.22 \%$ & $7 \%$ \\
\hline 4 & $\mathrm{Al}_{2} \mathrm{O}_{3}$ & $19.98 \%$ & $22.86 \%$ \\
\hline 5 & $\mathrm{Fe}_{2} \mathrm{O}_{3}$ & $7.98 \%$ & $9.83 \%$ \\
\hline 6 & $\mathrm{Ca} \mathrm{CO}_{3}$ & $6.38 \%$ & $8.5 \%$ \\
\hline 7 & $\mathrm{Mg} \mathrm{cO} 3$ & $9.62 \%$ & $8.80 \%$ \\
\hline 8 & Mgo & $6.56 \%$ & $2.9 \%$ \\
\hline 9 & Cao & $10.65 \%$ & $7 \%$ \\
\hline
\end{tabular}

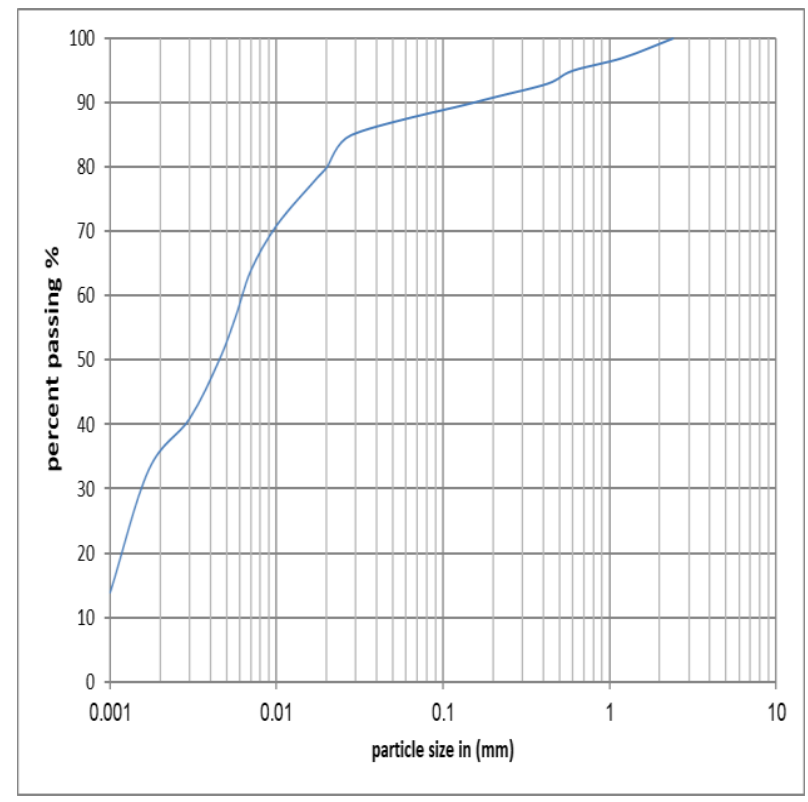

sample (A)

\section{LABORATORY EXPERIMENTS}

The physical and mechanical properties of the studied soil samples were determined accordance with the Egyptian code of soil mechanics and foundation design, part 2 [laboratory tests]. Those experiments shall measure the soil's engineering properties as follows:

- Unconfined compression strength

- Compaction Characterization

- Grain Size Distribution

- $\quad$ Physical Properties

o Specific Gravities

o Consistency Limits

- Consolidation Test

\section{ANALYSIS OF RESUlTS}

\section{A. Consistency Limits}

Different percentages of SF are mixed with soil samples as $0,2 \%, 4 \%, 6 \%, 8 \%$ and $10 \%$ of the weight of the dry soil weight for each soil sample, the physical properties 


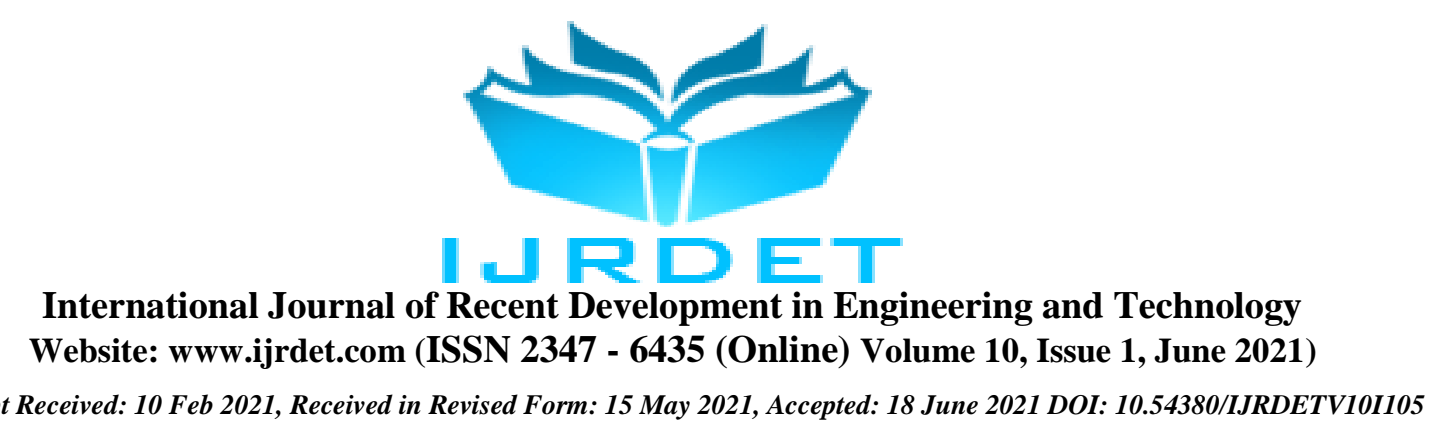

Manuscript Received: 10 Feb 2021, Received in Revised Form: 15 May 2021, Accepted: 18 June 2021 DOI: 10.54380/IJRDETV10I105

(LL, PL, and PI) are determined and the effect is described as the follows:

From fig. (2) Which shows the ratio of water content to the percentage of SF, it's clear that the LL increases with increasing the percentage of SF in soil samples, the PI values decrease with increasing the percentage of $\mathrm{SF}$ and the (PL) values slightly increase with increasing the amount of SF in soil samples.

\section{B. Compaction Characterization}

To determine the moisture-unit weight for all untreated test soils, a modified proctor compaction effort was used [8]. In figure 3, the influence of SF on OMC and $\gamma d$ max of soil is presented. The increase in the characterization of compaction due to the (SF) working as a filler material fills the voids in the soil and decreases it the $\gamma \mathrm{d}$ max values increase with increasing the percentage of SF.

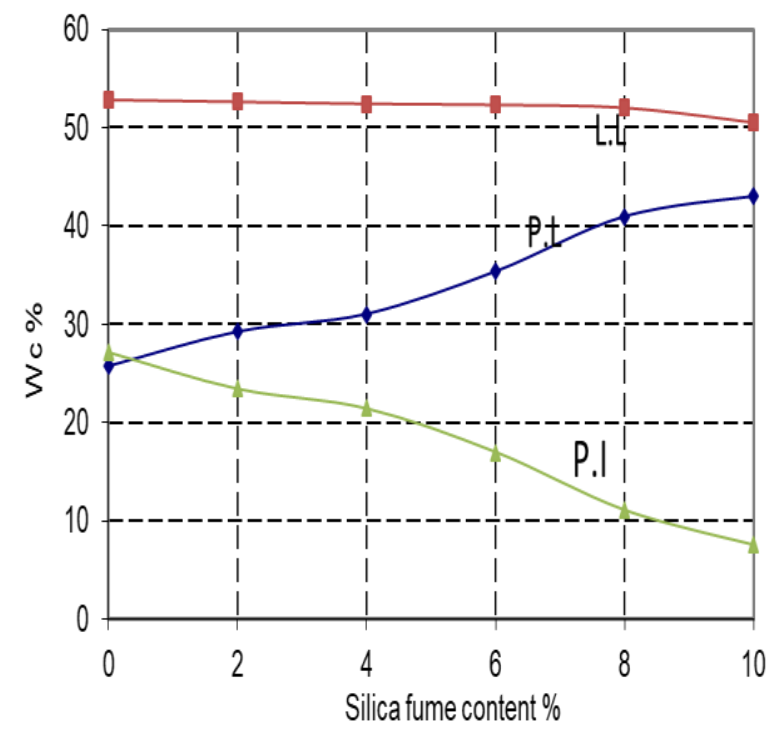

Soil (A)

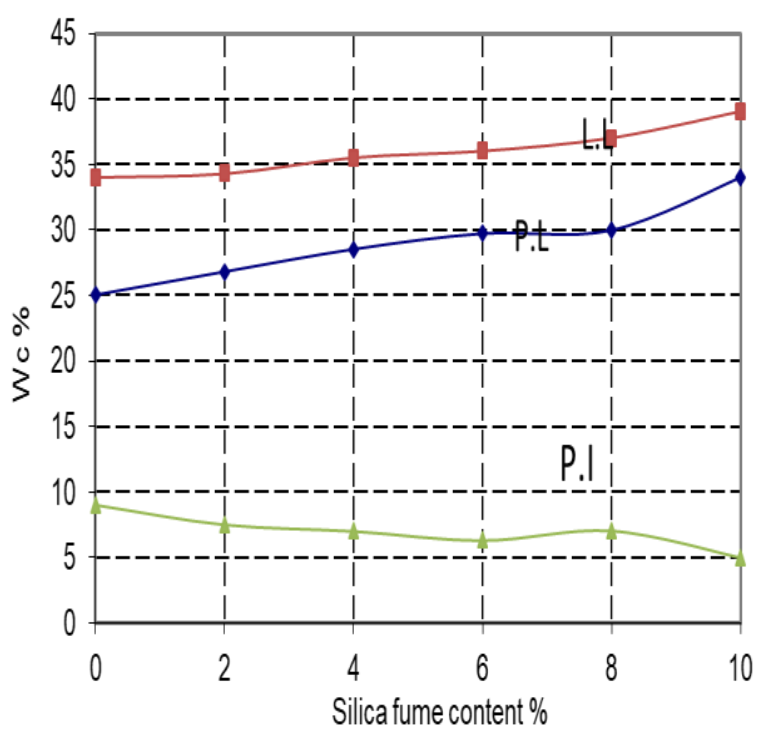

Soil (B)

Figure 2: SF content impact on consistency limits.

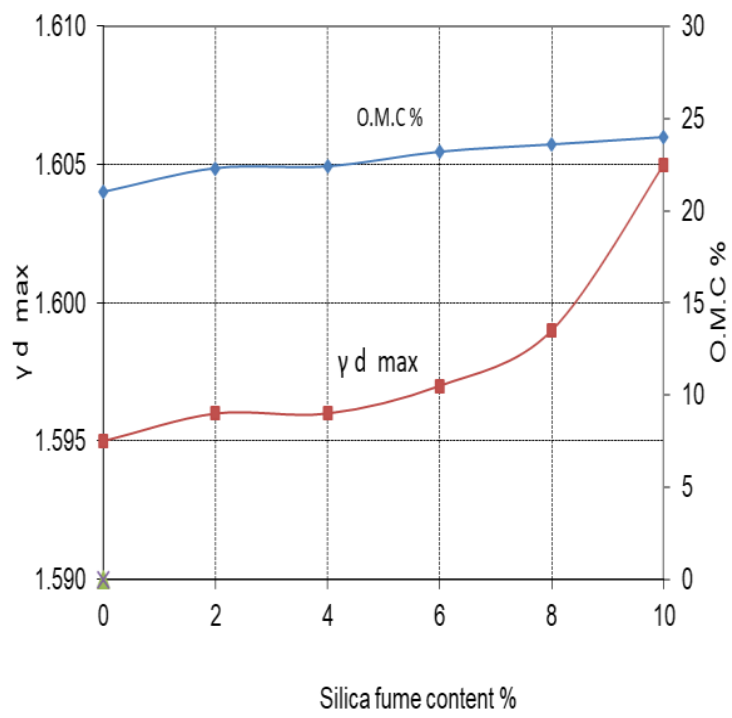

Soil (A) 


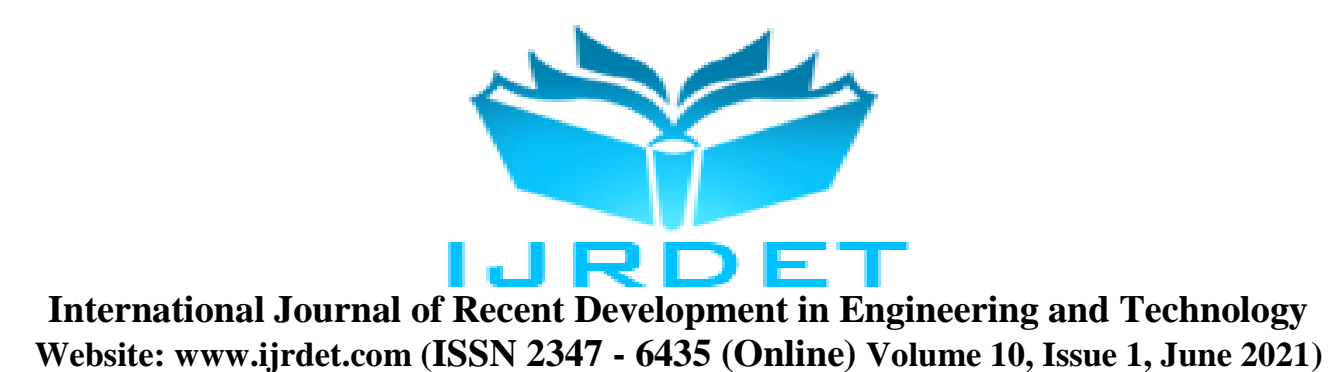

Manuscript Received: 10 Feb 2021, Received in Revised Form: 15 May 2021, Accepted: 18 June 2021 DOI: 10.54380/IJRDETV10I105

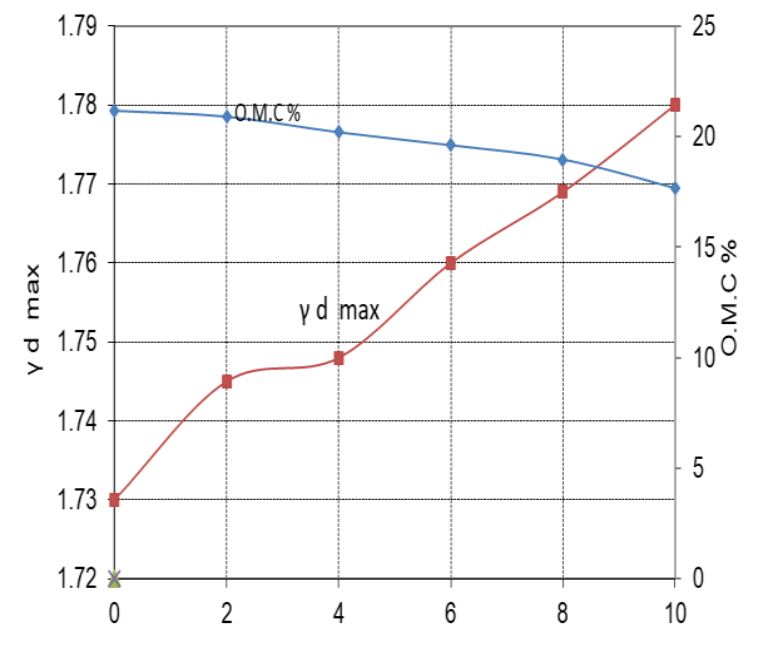

Silica fume content $\%$

Soil (B)

Figure 3: SF content impact on the compaction characterization.

\section{The permeability of collapsible soil}

Figure (8a) shows a tendency to decrease the value $(\mathrm{k})$ from $2.86 * 10-^{7}$ to $1.15 * 10-^{7}$ for soil (A) and to decrease from $1.48 * 10-^{7}$ to $1.13 * 10-^{8}$ for soil (B).

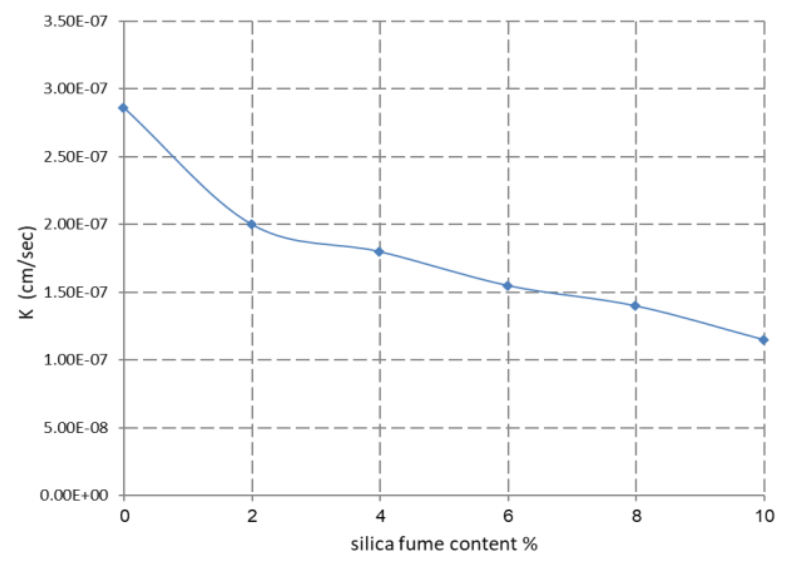

Soil (A)

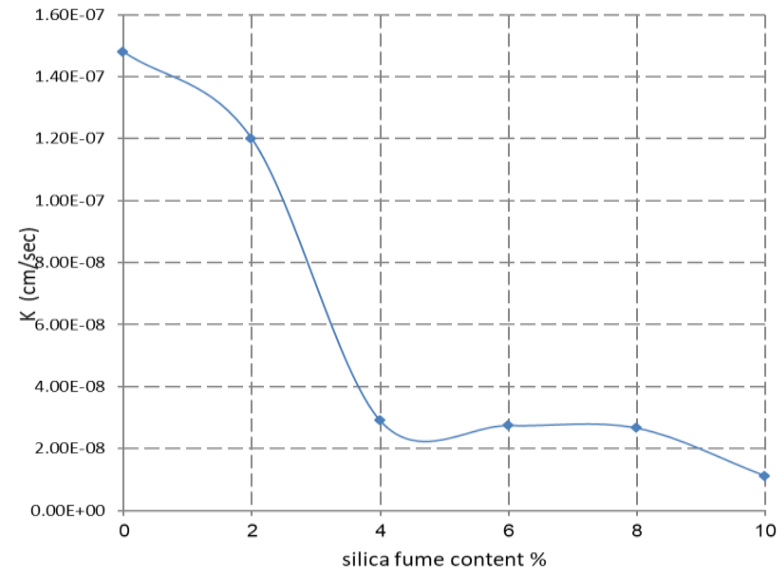

Soil (B)

Figure 8: SF content impact on the permeability of the compacted sample.

\section{Unconfined compression strength}

Results of the Unconfined compression strength test of samples with Mixed by different quantities of the (SF) $(0$, $2 \%, 4 \%, 6 \%, 8 \%$, and $10 \%$ ) are shown in fig (4). The (qu) unconfined compression strength of stabilized samples increases significantly with an increase in silica fume content from 0 percent to 10 percent (an improvement from 1.63 to $3.38 \mathrm{~kg} / \mathrm{cm}^{2}$.

However, after that, the unconfined compression strength is slightly affected by additional silica fume content. The increase in (qu)is due to silica fume particle internal friction and the chemical reaction between silica fume and soil. An increase in the amount of silica fume in soil has made the stabilized soil samples more porous than the natural soil samples, which is ductile compared to all the stabilized samples. 


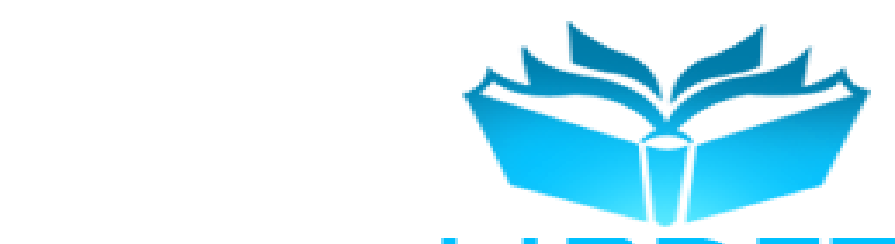

International Journal of Recent Development in Engineering and Technology

Website: www.ijrdet.com (ISSN 2347 - 6435 (Online) Volume 10, Issue 1, June 2021)

Manuscript Received: 10 Feb 2021, Received in Revised Form: 15 May 2021, Accepted: 18 June 2021 DOI: 10.54380/IJRDETV10I105
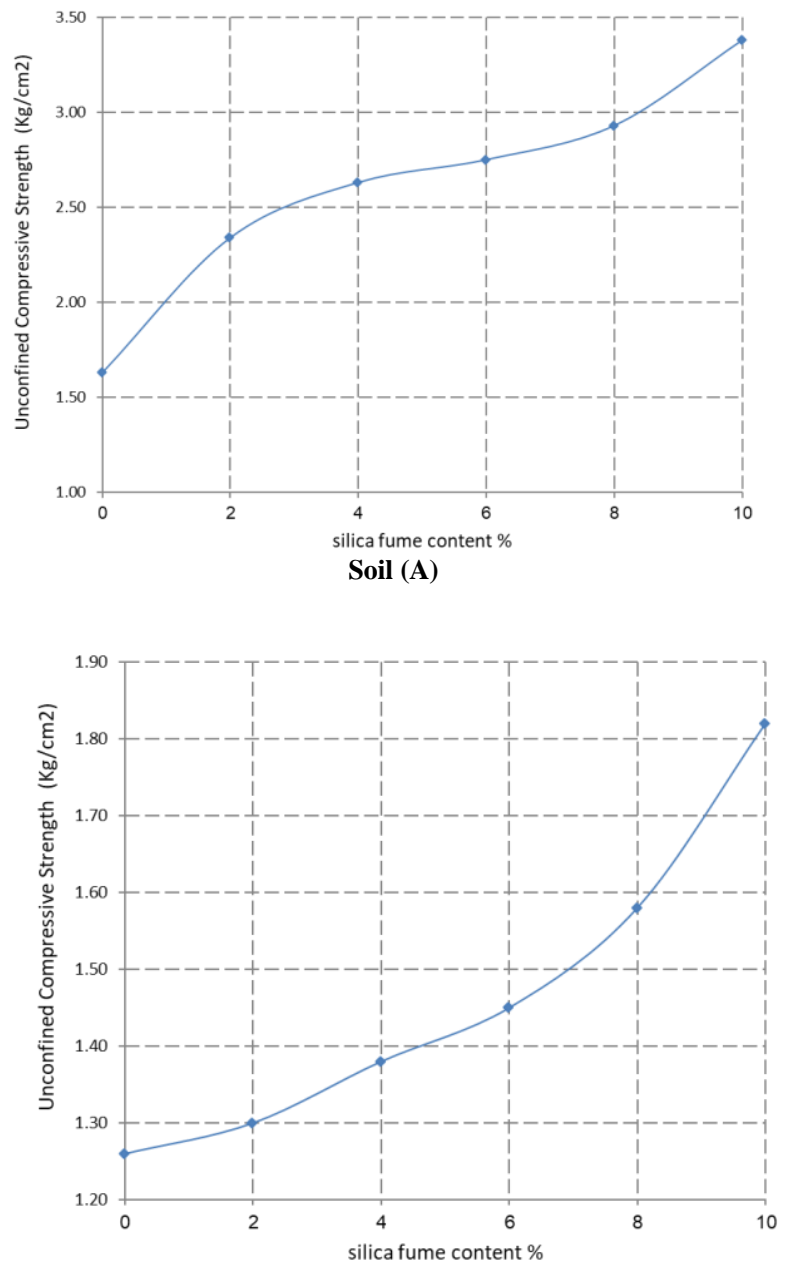

Soil (B)

Figure 4: Influence of SF content on the unconfined compression strength.

\section{E. Collapsible potential}

The collapsible potential (CP) of the undisturbed sample is $4.54 \%$ for soil (A) and $3.2 \%$ for soil (B). The Oedometer test results for compacted soils mixed with SF are shown in figure 5, Fig (5a) reveals a downward trend the value of $\mathrm{CP}$ from $4.54 \%$ to $2.52 \%$ for samples compacted at O.M.C soil (A). for soil (B) the CP value from $3.2 \%$ to $2.21 \%$ for samples compacted at O.M.C.

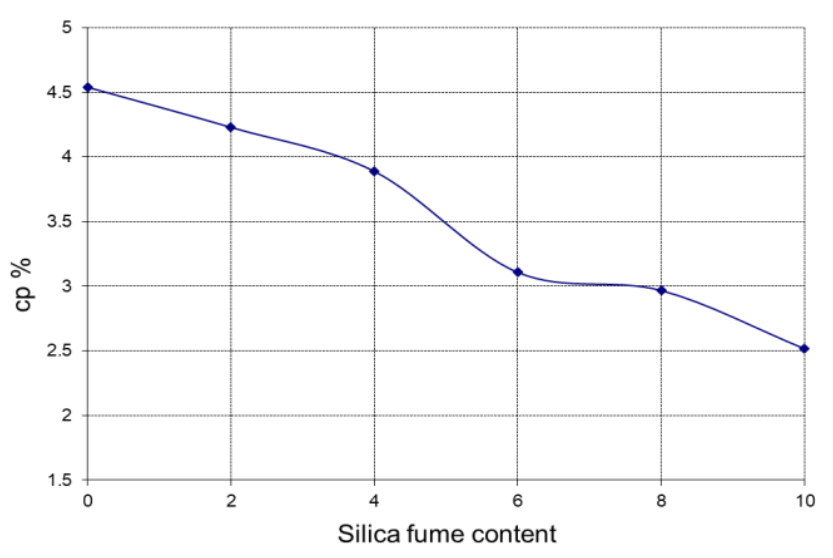

Soil (A)

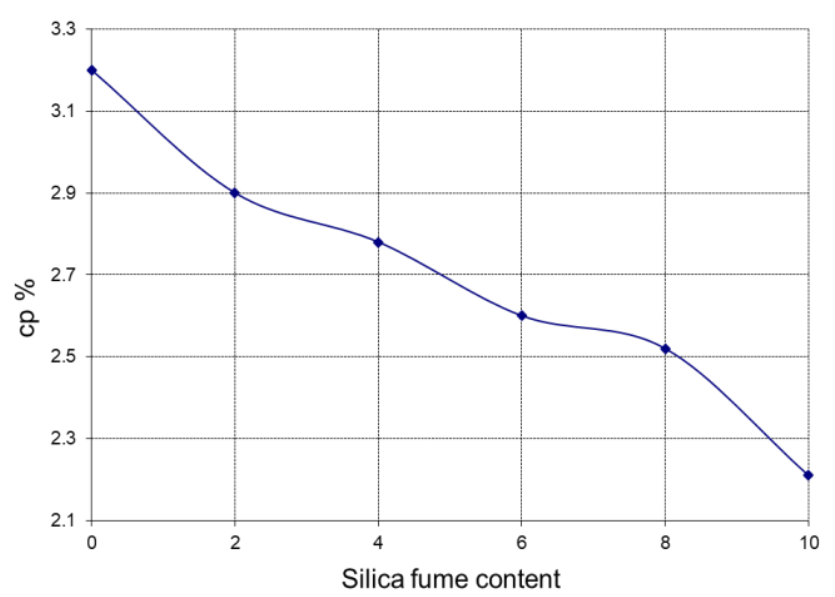

Soil (B)

Figure 9: Influence of SF content on the collapsible potential of the compacted sample.

\section{CONCLUSIONS}

The following general conclusions can be drawn on the basis of the analysis and discussion of the test results of the present study on the effect of silica fume on cohesive soil properties:

1. The increase in the (SF) amount led to an increase in liquid limit and decrees plasticity index values although it led to an increase in the plastic limit.

2. Increasing the amount of (SF) causes a slight increase in maximum dry density.

3. The collapsible potential decreases with increasing the silica fume solution injection. 


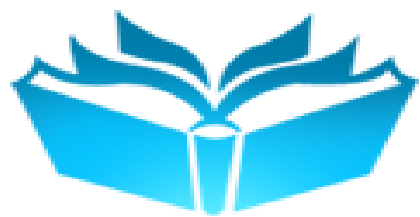 \\ IIRDET \\ International Journal of Recent Development in Engineering and Technology \\ Website: www.ijrdet.com (ISSN 2347 - 6435 (Online) Volume 10, Issue 1, June 2021) \\ Manuscript Received: 10 Feb 2021, Received in Revised Form: 15 May 2021, Accepted: 18 June 2021 DOI: 10.54380/IJRDETV10I105}

4. It was found that adding silica fume in the range of 0 $10 \%$ has improved the engineering properties of soil, such as Compaction Characterization because the silica fume is filler material that fills the voids in the soil and decreases it.

5. The unconfined compression strength of stabilized samples significantly increases from 0 percent to 10 percent (increase from 1.63 to $3.38 \mathrm{~kg} / \mathrm{cm}^{2}$ ) with increasing silica fume content. The increase in the (qu) is due to silica fume particle internal friction and the chemical reaction between silica fume and soil. An increase in the amount of silica fume in soil has made the stabilized soil samples more porous than the natural soil samples, which is ductile compared to all the stabilized samples.

6. The other properties such as collapsible potential, consistency limits and unconfined compression strength show improvements when mixed with the SF blend in the range of 0-10percent. (SF) is a highly effective pozzolanic material (silicon dioxide, $\mathrm{SiO}_{2}$ ) that reacts with clay minerals of the soil such as aluminum oxide, $\mathrm{Al}_{2} \mathrm{O}_{3}$ and produces aluminumsilicate hydrated cement (cemented material) with soil particles.

\section{REFERENCES}

[1] Chen, F.H., 1981. The foundation on Expansive Soil, Development in Geotechnical Engineering 12. Elsevier Scientific Publishing Company, New York, USA.

[2] Cokça, E., 1999. Effect of Fly Ash on Swell Pressure of an Expansive Soil, Electronic Journal of Geotechnical Engineering, Paper 9904. Oklahoma State University, USA.

[3] Houston, S., Houston, W., and Spadola, D. (1988). "Prediction of field collapse of soils due to wetting." Journal of Geotechnical Engineering, 114(1).

[4] Yoder, E.J. and Witczak, M.W., 1975. Principles of Pavement Design, 2nd Edition, John Wiley \& Sons, Inc., USA

[5] ACI Committee 226. 1987b. Silica fume in concrete: Preliminary report. ACI Materials Journal March-April: 158-66

[6] Luther, M. D. 1990. High-performance silica fume (micro-silica) Modified cementitious repair materials. 69th Annual Meeting of the Transportation Research Board, paper no. 890448 (January).

[7] Sreeramagiri, S.V.S., Bhavani, T. "Biomimetics and emerging trends in aviation technology" (2020) International Journal of Emerging Technology and Advanced Engineering, 10 (5), pp. 58-66.

[8] Alam, M.T., Ahsan, Q. A generalized stability model of a simultaneous AC-DC long transmission system (2020) International Journal of Emerging Technology and Advanced Engineering, 10 (4), pp. $45-53$.
[9] Tadesse, M., Giorgis, T.H. "Iternative energy resources potential of rift valley lakes basin of ethiopia: Potentials, challenges and future development perspective" (2020) International Journal of Emerging Technology and Advanced Engineering, 10 (2), pp. 1-18.

[10] Fonseca, D.J., Heim, I. "Development of an automated MATLABbased platform for the analysis of massive EEG datasets" (2020) International Journal of Emerging Technology and Advanced Engineering, 10 (11), pp. 7-11.

[11] Laber, J., Thamma, R. "MATLAB simulation for trajectory/path efficiency comparison between robotic manipulators" (2020) International Journal of Emerging Technology and Advanced Engineering, 10 (11), pp. 74-88.

[12] Mamiro, P.S., Mosha, Y.M., Mamiro, A.P. "A novel way of addressing eminent food insecurity challenges caused by American Fall Army Worms (Spodoptera Frugiperda)"(2020) International Journal of Emerging Technology and Advanced Engineering, 10 (11), pp. 12-23. 